\title{
Clinical utility gene card for: Lesch-Nyhan syndrome - update 2013
}

\author{
Rosa J Torres ${ }^{\star, 1}$, Juan G Puig ${ }^{2}$ and Irène Ceballos-Picot ${ }^{3}$ \\ European Journal of Human Genetics (2013) 21, doi:10.1038/ejhg.2012.304; published online 16 January 2013
}

Update to: European Journal of Human Genetics (2011) 19, doi:10.1038/ejhg.2010.109; published online 21 July 2010

\section{DISEASE CHARACTERISTICS}

1.1 Name of the disease (synonyms)

Hypoxanthine guanine phosphoribosyltransferase 1 deficiency

HGPRT deficiency

HPRT deficiency

HPRT deficiency, complete

Lesch-Nyhan disease

Lesch-Nyhan syndrome

\subsection{OMIM\# of the disease}

300322 .

1.3 Name of the analysed genes or DNA/chromosome segments HPRT1.

\subsection{OMIM\# of the gene(s)}

308000

\subsection{Mutational spectrum}

Human HPRT is encoded by a single structural gene spanning $\sim 45 \mathrm{~Kb}$ on the long arm of the $\mathrm{X}$ chromosome at Xq26, and consists of nine exons with a coding sequence of $654 \mathrm{bp}{ }^{1}$ Documented mutations in HPRT deficiency show a high degree of heterogeneity in type and location within the HPRT1 gene: deletions, insertions, duplications, and point mutations have been described as the cause of HPRT deficiency. To date, more than 300 disease-associated mutations have been found. ${ }^{2-4}$

\subsection{Analytical methods}

HPRT1 gene is a housekeeping gene and it is expressed in peripheral blood. Most HPRT-deficient patients, biochemically diagnosed by a null HPRT activity in erythrocytes, present HPRT mRNA expression, and molecular diagnosis can be accomplished by RNA extraction, reverse transcription polymerase chain reaction (RT-PCR), and HPRT cDNA (including $3^{\prime}$ and $5^{\prime}$ regions) sequencing. ${ }^{5-6}$ In other cases, HPRT gene mutations leading to the absence of HPRT mRNA (no transcription and/or mRNA instability), genomic DNA sequencing of the nine HPRT1 exons, with its intronic flanquing sequences, may be necessary. ${ }^{7}$ In some cases, the HPRT coding region is normal and the patients presents a decrease HPRT mRNA expression of unknown origin. In these patients quantification of HPRT mRNA by RT-PCR may be employed for molecular diagnosis. ${ }^{8-9}$ In a few cases, large deletion of regions of the HPRT gene, including the promoter, must be investigated by array comparative genomic hybridation (arrays CGH or aCGH) methodology.

Inheritance of HPRT deficiency is X-linked recessive. ${ }^{10-11}$ Thus males are generally affected and heterozygous female are carriers. However, at least five females with Lesch-Nyhan syndrome have been described, with different molecular alterations accounting for their HPRT deficiency. ${ }^{12-16}$ Carrier diagnosis is an important issue for most HPRT-deficient families. Female carriers cannot be detected without the help of a laboratory as they are usually asymptomatic. Carrier status cannot be accurately assessed by biochemical and enzymatic methods in most of the cases. HPRT activity is most often normal in haemolysate of the peripheral blood of female carriers due to selection against HPRT-deficient erythrocyte precursors. Enzymatic diagnosis of the carrier state can be performed by the identification of HPRT-deficient hair follicles or cultured fibroblasts because of their mosaicism in terms of HPRT activity, although such diagnosis is not infallible. ${ }^{17}$ HPRT-deficient cells from carrier females can be selected based on their six-thioguanine resistances. Proliferation assay of peripheral blood T-lymphocytes in the presence of six-thioguanine is diagnostic in most cases. ${ }^{18}$ However, faster and more accurate carrier diagnosis can be performed by molecular methods. Carrier diagnosis can be accomplished by genomic DNA sequencing of the HPRT1 gene fragment where the mutation was found in the family propositus. When propositus mutation is not available, amplification of the nine HPRT1 exons, with its intronic flankuing sequences, may be necessary. If a deletion has been found in the propositus, gene dosage may be accomplished by qPCR or MLPA. In those cases in which the patients HPRT coding region is normally associated with a decrease HPRT mRNA expression of unknown origin, ${ }^{8-9,19}$ quantification of HPRT mRNA by real time PCR may be employed for carrier diagnosis.

Prenatal diagnosis for Lesch-Nyhan syndrome can be performed with amniotic cells obtained by amniocentesis at about 15-18 weeks' gestation, or chorionic villus cells obtained at about 10-12 weeks' gestation. Both HPRT enzymatic assay and molecular analysis for the known disease-causing mutation can be performed. Quantification of HPRT mRNA by real time PCR may be employed for prenatal

\footnotetext{
${ }^{1}$ Biochemistry Laboratory, IdiPAZ-Instituto de Investigación Sanitaria del Hospital Universitario La Paz-Universidad Autónoma de Madrid, La Paz Hospital, Madrid, Spain; 2Internal Medicine Department, IdiPAZ- Instituto de Investigación Sanitaria del Hospital Universitario La Paz-Universidad Autónoma de Madrid, La Paz Hospital, Madrid, Spain; ${ }^{3}$ Metabolic Biochemistry Laboratory, Hôpital Necker-Enfants Malades, Paris, France

*Correspondence: Dr RJ Torres, Biochemistry Laboratory, IdiPAZ-Instituto de Investigación Sanitaria del Hospital Universitario La Paz-Universidad Autónoma de Madrid, La Paz Hospital, Paseo de la Castellana 261, Madrid 28046, Spain. Tel: +34 91727 7343; Fax: +34 91207 1468; E-mail: rtorres.hulp@salud.madrid.org
} 
diagnosis when a decrease HPRT mRNA expression is suspected as the cause of HPRT deficiency. ${ }^{20}$

\subsection{Analytical validation}

Mutation found in HPRT cDNA must be confirmed at genomic level.

1.8 Estimated frequency of the disease (incidence at birth ('birth prevalence') or population prevalence)

The prevalence of the disease is estimated to be $1 / 380000$ live births in Canada, and 1/235000 live births in Spain. ${ }^{21}$

1.9 If applicable, prevalence in the ethnic group of investigated person

\subsection{Diagnostic setting}

\begin{tabular}{lll}
\hline & Yes & No \\
A. (Differential) diagnostics & $\Downarrow$ & $\square$ \\
B. Predictive testing & $\square$ & $\square$ \\
C. Risk assessment in relatives & $\bigotimes$ & $\square$ \\
D. Prenatal & $\bigotimes$ & $\square$ \\
\hline
\end{tabular}

Comment:

When enzymatic diagnosis is not available clinical and molecular diagnosis must be performed.

\section{TEST CHARACTERISTICS}

\begin{tabular}{|c|c|c|c|c|}
\hline & \multicolumn{2}{|c|}{ Genotype or disease } & \multirow{2}{*}{$\begin{array}{l}\text { A: True positives } \\
\text { B: False positives }\end{array}$} & \multirow{2}{*}{$\begin{array}{l}\text { C: False negative } \\
\text { D: True negative }\end{array}$} \\
\hline & Present & Absent & & \\
\hline \multicolumn{5}{|l|}{ Test } \\
\hline \multirow[t]{2}{*}{ Positive } & A & $\mathrm{B}$ & Sensitivity: & $A /(A+C)$ \\
\hline & & & Specificity: & $D /(D+B)$ \\
\hline \multirow[t]{2}{*}{ Negative } & C & D & Positive predictive value: & $A /(A+B)$ \\
\hline & & & Negative predictive value: & $\mathrm{D} /(\mathrm{C}+\mathrm{D})$ \\
\hline
\end{tabular}

\subsection{Analytical sensitivity}

(proportion of positive tests if the genotype is present)

About $95 \%$ (in a $5 \%$ of patients the molecular defect causing HPRT deficiency is not found. These patients present decreased HPRT1 expression of unknown cause $)^{8-9,19}$

\subsection{Analytical specificity} (proportion of negative tests if the genotype is not present) $100 \%$.

\subsection{Clinical sensitivity}

(proportion of positive tests if the disease is present)

The clinical sensitivity can be dependent on variable factors such as age or family history. In such cases a general statement should be given, even if a quantification can only be made case by case.

About $95 \%$ (in a $5 \%$ of patients the molecular defect causing HPRT deficiency is not found. These patients present decreased HPRT1 expression of unknown cause)

\subsection{Clinical specificity}

(proportion of negative tests if the disease is not present)
The clinical specificity can be dependent on variable factors such as age or family history. In such cases a general statement should be given, even if a quantification can only be made case by case.

$100 \%$.

\subsection{Positive clinical predictive value}

(life time risk to develop the disease if the test is positive). $100 \%$.

\subsection{Negative clinical predictive value} (probability not to develop the disease if the test is negative) Assume an increased risk based on family history for a non-affected person. Allelic and locus heterogeneity may need to be considered. Index case in that family had been tested: $100 \%$.

Index case in that family had not been tested: $100 \%$.

\section{CLINICAL UTILITY}

3.1 (Differential) diagnostics: the tested person is clinically affected (To be answered if in 1.10 'A' was marked)

\subsubsection{Can a diagnosis be made other than through a genetic test?}

\begin{tabular}{lll}
\hline No & $\square$ (continue with 3.1.4) \\
Yes & $\bigotimes$ & \\
& Clinically & \\
Imaging & $\square$ \\
& Endoscopy & $\square$ \\
Biochemistry & $\square$ \\
& Electrophysiology & $\square$ \\
& Other (please describe) &
\end{tabular}

3.1.2 Describe the burden of alternative diagnostic methods to the patient

Enzymatic test for HPRT activity in haemolysate or intact cells are of diagnostic and pronostic value.

3.1.3 How is the cost effectiveness of alternative diagnostic methods to be judged?

Enzymatic test are laborious and they are not available in many laboratories (see www.lesch-nyhan.org and orpha.net for the list).

3.1.4 Will disease management be influenced by the result of a genetic test?

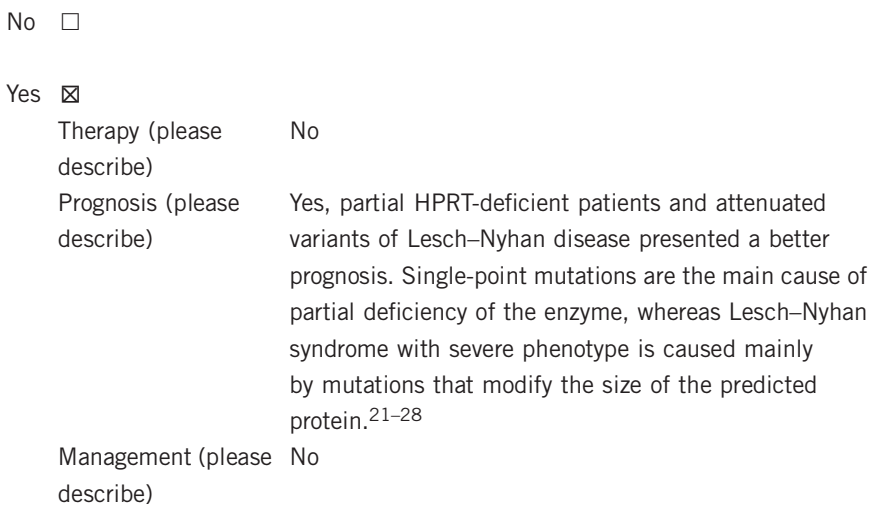


3.2 Predictive setting: the tested person is clinically unaffected but carries an increased risk based on family history

(To be answered if in 1.10 ' $\mathrm{B}$ ' was marked)

\subsubsection{Will the result of a genetic test influence lifestyle and} prevention?

If the test result is positive (please describe)

If the test result is negative (please describe)

3.2.2 Which options in view of lifestyle and prevention does a person at-risk have if no genetic test has been done (please describe)?

3.3 Genetic risk assessment in family members of a diseased person

(To be answered if in 1.10 ' $\mathrm{C}$ ' was marked)

Molecular testing of potential heterozygous carrier in a family

\subsubsection{Does the result of a genetic test resolve the genetic situation in} that family?

Yes

\subsubsection{Can a genetic test in the index patient save genetic or other} tests in family members?

No

3.3.3 Does a positive genetic test result in the index patient enable a predictive test in a family member?

Yes

\subsection{Prenatal diagnosis}

(To be answered if in 1.10 ' $D$ ' was marked)

Prenatal diagnosis possible when the causal mutation identified in the index case and diagnosis of the carrier done

\subsubsection{Does a positive genetic test result in the index patient enable a prenatal diagnostic?}

Yes

\section{IF APPLICABLE, FURTHER CONSEQUENCES OF TESTING}

Please assume that the result of a genetic test has no immediate medical consequences. Is there any evidence that a genetic test is nevertheless useful for the patient or his/her relatives? (please describe)

Molecular diagnosis in the proband allows a more accurate and faster carrier and prenatal diagnosis in relatives.

\section{CONFLICT OF INTEREST}

The authors declare no conflict of interest.

\section{ACKNOWLEDGEMENTS}

This work was supported by EuroGentest, an EU-FP6 supported NoE, contract number 512148 (EuroGentest Unit 3: 'Clinical genetics, community genetics and public health', Workpackage 3.2).

1 Edwards A, Voss H, Rice $\mathrm{P}$ et al: Automated DNA sequencing of the human HPRT locus. Genomics 1990; 6: 593-608.
2 Jinnah HA, De Gregorio L, Harris JC, Nyhan WL, O'Neill JP: The spectrum of inherited mutations causing HPRT deficiency: 75 new cases and a review of 196 previously reported cases. Mutat Res 2000; 463: 309-326.

3 Torres RJ, Mateos FA, Molano J et al: Molecular basis of hypoxanthine-guanine phosphoribosyltransferase deficiency in thirteen Spanish families. Hum Mutat 2000; 15: 383.

4 Official website of the Lesch-Nyhan disease International Study Group. www. lesch-nyhan.org.

5 Wilson JM, Stout JT, Palella TD, Davidson BL, Kelley WN, Caskey CT: A molecular survey of hypoxanthine-guanine phosphoribosyltransferase deficiency in man. J Clin Invest 1986; 77: 188-195.

6 Davidson BL, Tarle SA, Palella TD, Kelley WN: Molecular basis of hypoxanthineguanine phosphoribosyltransferase deficiency in ten subjects determined by direct sequencing of amplified transcripts. J Clin Invest 1989; 84: 342-346.

7 Gibbs RA, Nguyen PN, Edwards A, Civitello AB, Caskey CT: Multiplex DNA deletion detection and exon sequencing of the hypoxanthine phosphoribosyltransferase gene in Lesch-Nyhan families. Genomics 1990; 7: 235-244.

8 Dawson PA, Gordon RB, Keough DT, Emmerson BT: Normal HPRT coding region in a male with gout due to HPRT deficiency. Molec Genet Metab 2005; 85: 78-80.

9 García MG, Torres RJ, Prior C, Puig JG: Normal HPRT coding region in complete and partial HPRT deficiency. Mol Genet Metab 2008; 94: 167-172.

10 Lesch M, Nyhan WL: A familial disorder of uric acid metabolism and central nervous system function. Am J Med 1964; 36: 561-570.

11 Seegmiller JE, Rosenbloom FM, Kelley WN: Enzyme defect associated with a sex-linked human neurological disorder and excessive purine synthesis. Science 1967; 155: 1682-1684.

12 Ogasawara N, Stout JT, Goto H, Sonta SI, Matsumoto A, Caskey CT: Molecular analysis of a female Lesch-Nyhan patients. J Clin Invest 1989; 84: 1024-1027.

13 Rinat C, Zoref-Shani E, Ben-Neriah Z et al: Molecular, biochemical, and genetic characterization of a female patient with Lesch-Nyhan disease. Mol Genet Metab 2006; 87: 249-252

14 De Gregorio L, Jinnah HA, Harris JC et al: Lesch-Nyhan disease in a female with a clinically normal monozygotic twin. Mol Genet Metab 2005; 85: 70-77.

15 De Gregorio L, Nyhan WL, Serafin E, Chamoles NA: An unexpected affected female patient in a classical Lesch-Nyhan family. Mol Genet Metab 2000; 69: 263-268.

16 Aral B, de Saint BasileG, Al-Garawi S, Kamoun P, Ceballos-Picot I: Novel nonsense mutation in the hypoxanthine guanine phosphoribosyltransferase gene and nonrandom X-inactivation causing Lesch-Nyhan syndrome in a female patient. Hum Mutat 1996; 7: 52-58.

17 Page T, Bakay B, Nissinen E, Nyhan WL: Hypoxanthine-guanine phosphoribosyltransferase variants: correlation of clinical phenotype with enzyme activity. $J$ Inherit Metab Dis 1981; 4: 203-206.

18 O'Neill JP: Mutation carrier testing in Lesch-Nyhan syndrome families: HPRT mutant frequency and mutation analysis with peripheral blood T lymphocytes. Genet Test 2004; 8: 51-64.

19 Nguyen KV, Naviaux RK, Paik KK, Nyhan WL: Lesch-Nyhan syndrome: mRNA expression of HPRT in patients with enzyme proven deficiency of HPRT and normal HPRT coding region of the DNA. Mol Genet and Metab 2012; 106: 498-501.

20 Torres RJ, Garcia MG, Puig JG: Carrier and prenatal diagnosis of Lesch-Nyhan disease due to a defect in HPRT gene expression regulation. Gene 2012; 511: 306-307.

21 Torres RJ, Puig JG: Hypoxanthine-guanine phosophoribosyltransferase (HPRT) deficiency: Lesch-Nyhan syndrome. Orphanet J Rare Dis 2007; 2: 48.

22 Kelley WN, Rosenbloom FM, Henderson JF, Seegmiller JE: A specific enzyme defect in gout associated with overproduction of uric acid. Proc Natl Acad Sci USA 1967; 57: 1735-1739

23 Puig JG, Torres RJ, Mateos F et al: The spectrum of hypoxanthine-guanine phosphoribosyltransferase (HPRT) deficiency. Clinical experience based on 22 patients from 18 Spanish families. Medicine (Balt) 2001; 80: 102-112.

24 Dussol B, Ceballos-Picot I, Aral B, Castera V, Philip N, Berland Y: Kelley-Seegmiller syndrome due to a new variant of the hypoxanthine-guanine phosphoribosyltransferase (I136T) encoding gene (HPRT Marseille). J Inherit Metab Dis 2004; 27: 543-545.

25 Ea HK, Bardin T, Jinnah HA, Aral B, Lioté F, Ceballos-Picot I: Severe gouty arthritis and mild neurologic symptoms due to F199C, a newly identified variant of the hypoxanthine guanine phosphoribosyltransferase. Arthritis Rheum 2009; 60: 2201-2204

26 Jinnah HA, Visser JE, Harris JC et al: Lesch-Nyhan Disease International Study Group. Delineation of the motor disorder of Lesch-Nyhan disease. Brain 2006; 129: 1201-1217.

27 Jinnah HA, Ceballos-Picot I, Torres RJ et al: Lesch-Nyhan Disease International Study Group. Attenuated variants of Lesch-Nyhan disease. Brain 2010; 133: 671-689.

28 Fu R, Jinnah HA: Genotype-phenotype correlations in Lesch-Nyhan disease: moving beyond the gene. J Biol Chem 2012; 287: 2997-3008. 